\title{
Insecurisme Politik Rakyat Indonesia pada Pemilihan Kepala Daerah 2020
}

\author{
${ }^{1}$ Al Mukhollis Siagian, ${ }^{2}$ Yuli Permatasari \\ ${ }^{1}$ Program Studi Ilmu Administrasi Publik, Universitas Negeri Padang \\ almukhollis1998@gmail.com \\ ${ }^{2}$ Program Pascasarjana Bimbingan Konseling, Universitas Negeri Padang \\ ypermatasari17@gmail.com
}

\begin{abstract}
Abstrak
Salah satu masalah penting dari demokrasi daerah adalah politik kekerabatan. Terdapat 124 calon kepala daerah pada pemilihan umum kepala daerah 2020 di Indonesia terpapar politik kekerabatan. Demokrasi sebagai sistem yang memposisikan rakyat pemegang kedaulatan telah kehilangan ruhnya. Penelitian ini bertujuan untuk menginterpretasikan fenomena politik kekerabatan pada pilkada tahun 2020 dengan pisau analisis psikologi dari sisi rakyat. Metode penelitian yang digunakan adalah systematic literatur review. Hasil penelitian menemukan sepuluh faktor dominan penyebab terjadinya insecurisme politik rakyat; rendahnya kesadaran politik rakyat, minimnya edukasi politik kepada rakyat, partisipasi politik rakyat bersifat passif, pragmatisme partai politik pada kandidasi calon kepala daerah, ketidakpercayaan rakyat terhadap calon kepala daerah, lemahnya sosialisasi KPU terhadap rakyat tentang pentingnya penggunaan suara dalam menentukan kondisi daerah, pemutakhiran data pemilih, tingginya modus transaksi calon kepala daerah kepada rakyat, formalitas ketentuan calon kepala daerah, dan kran politik kekerabatan dibuka secara leluasa melalui Undang-Undang Nomor 6 Tahun 2020 tentang tentang Pemilihan Gubernur, Bupati, dan Walikota. Kemudian sepuluh faktor tersebut membentuk insecurisme politik rakyat Indonesia. Rakyat memposisikan dirinya tidak berdaya dan beranggapan tidak memiliki pengaruh dalam demokrasi sehingga melakukan pengabaian atas maraknya politik kekerabatan.
\end{abstract}

Kata Kunci: Partisipasi Politik Rakyat, Pilkada 2020, Politik Kekerabatan, Insecurisme Politik Rakyat Indonesia

\begin{abstract}
One of the important problems of regional democracy is the politics of kinship. There are 124 regional head candidates in the 2020 regional head election in Indonesia exposed to kinship politics. Democracy as a system that positions the people holding sovereignty has lost its spirit. This study aims to interpret the phenomenon of kinship politics in the 2020 elections with a psychological analysis knife from the people's side. The research method used is a systematic literature review. The results of the study found ten dominant factors causing people's political insecurism; low political awareness of the people, lack of political education to the people, passive political participation of the people, pragmatism of political parties in the candidacy of regional head candidates, people's distrust of regional head candidates, the weak socialization of the KPU to the people about the importance of using votes in determining regional conditions, updating voter data, the high transaction mode of regional head candidates to the people, the formality of provisions for regional head candidates, and the political faucet of kinship is opened freely through Law Number 6 of 2020 concerning Election of governors, regents and mayors. Then these ten factors shape the political insecurism of the Indonesian people. The people position themselves as helpless and think they have no influence in democracy so that they ignore the rise of kinship politics. and political kinship faucets are opened freely through Law Number 6 of 2020 concerning the Election of Governors, Regents, and Mayors. Then these ten factors shape the political insecurism of the Indonesian people. The people position
\end{abstract}


themselves as helpless and think they have no influence in democracy so that they ignore the rise of kinship politics. and political kinship faucets are opened freely through Law Number 6 of 2020 concerning the Election of Governors, Regents, and Mayors. Then these ten factors shape the political insecurism of the Indonesian people. The people position themselves as helpless and think they have no influence in democracy so that they ignore the rise of kinship politics.

Keywords: People's Political Participation, 2020 Pilkada, Kinship Politics, Indonesian People's Political Insecurity

\section{Pendahuluan}

Beberapa tahun belakangan ini kita menyaksikan gelombang kemerosotan demokrasi secara nasional dan telah banyak studi mengkonfirmasi bahwa salah satu alasan belum berakarnya demokrasi dengan baik di Indonesia dikarenakan rakyat belum sepenuhnya memahami peran mereka dengan tepat. Indonesia pernah disanjung sebagai negara demokrasi terbesar ketiga di dunia, kemudian mengalami kemerosotan. Kemerosotan itu dapat dilihat dari laporan EIU yang memaparkan bahwa Indonesia berada pada urutan ke-64 dari 167 negara. Begitu juga dengan laporan Indeks Demokrasi Indonesia yang menunjukkan turunnya skor indeks kebabasan berpendapat dari 66,17 tahun 2018 menjadi 64,29 tahun 2019. Bahkan pada tahun 2021 laporan Democracy Report memperlihatkan bahwa Indonesia berada di urutan 73 dari 179 negara. Jati W. R., (2021) dalam menanggapi kemerosotan demokrasi di Indonesia mengemukakan bahwa ada tiga faktor penyebab, diantaranya adalah menguatnya peran aktif militer dalam peran sipil, menguatnya hubungan tidak harmonis antara kubu nasionalis-pluralis dengan konservatif, dan favoritisme politik menjadi tendensi dinasti politik. Pemikiran Jati diatas tidak cukup baik dalam menganalisis kemerosotan demokrasi dari sisi pengendalian demokrasi (kekuasaan) saja. Sehingga analisis demikian menimbulkan bias dan seolah-olah rakyat adalah objek dari demokrasi. Jelas bahwa demokrasi yang tampuk kedaulatannya berada pada kehendak rakyat harus dikaji secara utuh dari sisi rakyat itu sendiri. Sehingga kemerosotan demokrasi yang terjadi di Indonesia tetap harus dikaji dari sisi rakyat dalam keterlibatannya secara aktif pada proses politik konstruktif. Rakyat harus mampu menelaah secara kritis dan holistik serta memiliki kebijaksanaan dalam memastikan bahwa masalah mereka ditanggapi secara serius dan tepat oleh penyelenggara pemerintahan (eksekutif dan legislatif) adalah aktualitas dari demokrasi. Penetapan agenda kebijakan, mulai dari formulasi hingga pengesahannya tidak pernah lepas dari proses politik sebagaimana konsep sistem yang digagas oleh David Easton dalam Chilcote (2003: 222) terdiri dari input, proses, output, dan feedback.

Demokrasi sebagai konstruksi sistem yang berorientasi pada rakyat kerap ditemukan sikap apatis dari rakyat bahkan mengenai apa yang berkaitan dengan mereka. Sebagaimana para peneliti (Ardiyanti dan Zulian, 2018 ; Agustino dan Yusoff, 2020) memperlihatkan bahwa apatisme rakyat dalam berpolitik masih tinggi dan ini merupakan bahaya dalam demokrasi. Ini adalah bukti teoritis dan empiris terhadap proses demokrasi mengalami kegagalan. "Jangan ajari kami apa yang harus dilakukan dengan kondisi politik hari ini, kami tidak mau terusik oleh ketiksopanan para politisi yang menggoda lalu meninggalkan disaat kepercayaan telah mereka dapatkan" adalah ungkapan paling sering muncul penulis peroleh disaat melakukan edukasi politik dan penyadaran peran rakyat dalam perpolitikan Negara, dengan sistem demokrasi, posisi rakyat ditinggikan, seharusnya itu berlaku dan berjalan tanpa harus menggunakan kata "seharusnya" (Siagian, 2021). 
Lebih lanjut, sikap apatisme dan skeptisme rakyat tentang posisi dan peran mereka dalam demokrasi menciptakan terjadinya pembalikan standar demokrasi yang bertahap oleh elit aktor (politik, sosial, ekonomi, agama, dll.) tampaknya telah menyalip reformasi, restorasi, revolusi, kudeta, dan flatform gerakan sosial lainnya maupun intervensi eksternal sebagai ancaman terbesar dalam demokrasi. Dari berbagai kasus, perkembangan ini dipicu oleh politisi dari lingkar kekerabatan elit yang memasuki pemerintahan dan melakukan reformasi kelembagaan. Banyak dari dinamika tersebut telah dibahas dan didokumentasikan dengan baik, karena literatur tentang politik kekerabatan dan dampaknya terhadap demokrasi pun tengah berkembang.

Sehingga politik kekerabatan merupakan salah satu sorotan akademis bernilai penting dari demokrasi dewasa ini. Kehadiran politik kekerabatan memiliki keterkaitan erat dengan maraknya politisi populis, membuat kita harus dengan pemahaman lengkap hendak melakukan pembahasan tentang politik kekerabatan yang telah berubah menjadi populisme politik dan implikasinya untuk pemerintahan demokratis. Terjadinya kemerosotan demokrasi merupakan konsep kontroversial yang ambiguitasnya telah mempersulit perdebatan secara sistematis. Banyak pemahaman tentang demokrasi lebih bernuansa, bahkan gagasan liberalism di Negara paling demokratis dunia (Amerika Serikat) pun menuai banyak kritik.

Apabila menelaah logika ini lebih dalam, maka populisme politisi adalah kemudi demokrasi anti-pluralis. Dimana anti-pluralisme tentu bertentangan dengan gagasan modern demokrasi. Tingkat pluralisme tinggi merupakan kondisi yang diperlukan sebagai karakteristik penting dan konsekuensi dari Negara demokratis. Kehendak bersama rakyat tidak ada apriori, melainkan hanya bisa terwujud dengan kompromi kepentingan dalam suasana pluralis. Ini tidak menghalangi konsensus luas tentang kebijakan tertentu, tetapi menjamin opsi untuk menyuarakan ketidaksepakatan. Demokrasi pada prinsipnya harus memiliki aturan permainan politik yang adil, norma hukum teguh, dan kesopanan sebagai prinsip interaksi rakyat.

Argumen ini mungkin tampak intuitif mengenai lembaga-lembaga politik, relevansinya untuk politik kekerabatan agak meragukan pada pandangan pertama. Kearifan konvensional menyatakan bahwa politisi melaksanakan apa yang diminta aktor elit. Dan jika tidak, yang terakhir harus menemukan cara lebih baik untuk mengendalikan dan menyetir para politisi. Meskipun dalam pandangan praktik empiris, interaksi antara aktor elit dan politisi begitu beragam dan kompleks. Kontrol elit atas politisi tidak pernah lepas, oleh karena itu pertanyaan tentang kualitas demokrasi pada pemilihan kepala daerah menjadi relevan. Skenario ini memunculkan keprihatinan interpretatif dan analitis. Politik kekerabatan telah berhasil terstimulus dalam pikiran rakyat sebagai fenomena yang wajar dan seolah-olah tidak mengandung masalah. Kondisi ini diikuti oleh logika elit untuk mempertahankan status quo. Dalam sistem politik modern, upaya reformasi seperti itu sering dilakukan.

Apabila merujuk dari laporan Nagara Institute terdapat sebanyak 124 calon kepala daerah terpapar politik kekerabatan pada Pilkada serentak 2020. Dibandingkan dengan pilkada serentak sebelum-sebelumnya, pilkada serentak dari tahun 2015 hingga tahun 2018 hanya sebanyak 86 calon terpapar politik kekerabatan. Maraknya politik kekerabatan dalam pilkada merupakan bukti bahwa rakyat sebagai ruh demokrasi telah kehilangan arah dan para aktor elit melanggengkan serta memperluas jangkauan posisi strategis yang harus dikuasai dengan menghadirkan politisi populis (lingkar kerabat).

Fenomena ini merupakan keresahan akdemis yang memiliki implikasi buruk pada keberlangsungan praktik-praktik politik dalam demokrasi kita. Apabila menelaah lebih dalam, penulis menarik asumsi bahwa fenomena ini terbentuk dari insecurisme rakyat dalam perpolitikan demokrasi. Logikanya adalah rakyat sebagai jiwa daripada demokrasi 
menghendaki kualitas raganya (Negara). Maksud dari insecurisme politik rakyat disini adalah pemahaman rakyat yang telah memposisikan diri tidak pantas untuk mengikuti kontestasi politik di arena pemilihan umum, sehingga memunculkan dua pertanyaan akademis bernilai penting. Pertama, faktor apa yang membuat maraknya politik kekerabatan dari sisi rakyat Indonesia pada pemilihan kepala daerah? Kedua, apakah faktor-faktor tersebut telah menjadi pemahaman kolektif-kolegial perpolitikan rakyat Indonesia pada pemilihan kepala daerah 2020 sehingga layak dikatakan insecurisme politik rakyat?

\section{Metode}

Artikel ini ditulis dengan telaah terhadap penelitian-penelitian sebelumnya yang membahas tentang politik kekerabatan pada pilkada dari sisi rakyat. Metode penelitian yang digunakan adalah systematic literatur review. Penelitian ini bertujuan untuk menginterpretasikan fenomena politik kekerabatan pada pilkada tahun 2020 dengan pisau analisis psikologi dari sisi rakyat. Teknik analisisnya menggunakan desain meta-sintesis kualitatif interpretatif. Materi dalam penulisan artikel review ini adalah partisipasi politik rakyat, pilkada 2020, politik kekerabatan, dan insecurisme politik rakyat Indonesia.

Prosedur penelitian dilakukan dengan mengawali identifikasi artikel yang direview diidentifikasi melalui kata kunci; partisipasi politik rakyat, pilkada 2020, politik kekerabatan, dan insecurisme politik rakyat Indonesia melalui pencarian di google scholar dari tahun 20152020. Jumlah artikel yang ditemukan sebanyak 34.570 artikel. Kemudian, penulis melakukan focusing judul melalui kata kunci, maka jumlah data yang tidak termasuk dalam kategori penulis butuhkan terdapat sebanyak 30.000 artikel.

Berdasarkan hasil penyaringan judul, jumlah artikel yang memenuhi kriteria sebanyak 4.570 artikel. Selanjutnya penulis melakukan pengecualian terhadap artikel yang tidak sesuai dengan fokus penulis berdasarkan hasil yang termaktub pada abstrak. Jumlah artikel tersebut sebanyak 4.500 artikel. Hasil yang diperoleh sesuai dengan materi dari pembacaan abstrak sebanyak 70 artikel. Dari 70 artikel, penulis masuk pada tahap baca teks secara keseluruhan, diperoleh artikel yang tidak relevan sebanyak 60 artikel. Sehingga 10 artikel paling tepat dan sesuai penulis lakukan review artikel.

\section{Hasil dan Pembahasan}

2020 merupakan salah satu tahun pesta politik Indonesia, menggelar kontestasi demokrasi pemilihan kepala daerah secara serentak sebanyak 270 daerah yang terdiri dari 9 provinsi, 224 kabupaten, dan 37 kota. Kontestasi pilkada tahun 2020 lebih banyak dibandingkan tahun-tahun sebelumnya. Sebagai perbandingan pada tahun 2018 sebanyak 171 daerah, di tahun 2017 sebanyak 101 daerah, dan tahun 2015 sebanyak 269 daerah. Akan tetapi, jumlah daerah yang melangsungkan pilkada di tahun 2020 berbanding lurus dengan bertambahnya problematika negeri ini, dimana sebanyak 124 calon kepala daerah terpapar politik kekerabatan.

Indonesia memiliki dasar sistem citizen law melalui amanat konstitusi yang menyatakan bahwa kedaulatan tertinggi berada ditangan rakyat, maka semua kondisi ini, baik atau buruknya tergantung pada hukum stimulus dan respon pemilih (politik rakyat) terhadap politisi dan regulasi. Logika demokrasi di Indonesia yang dimaktubkan dalam konstitusi (UUD 1945) berbeda dengan demokrasi di Negara-negara lain belahan dunia, bahwasanya demokrasi memberikan sepenuhnya kendali ditangan rakyat. Sehingga demokrasi bukanlah normalisasi atas kedaruratan untuk Indonesia yang berasal dari Negara. Lagian, bukankah Aristoteles sebagai orang pertama memperkenalkan konsep politik juga mengemukakan 
bahwa hakikat dari realitas kehidupan sosial adalah politik. Itu berarti kunci dari perbaikan politik berada ditangan rakyat.

Apabila rakyat masih suka dengan hoax, para politisi akan menjajakan data statistik mereka dengan semenarik mungkin agar terlihat mempunyai landasan akademik yang valid untuk sebuah pembenaran (hoax); apabila rakyat masih suka dengan politik uang, para politisi akan menawarkan uang tertinggi untuk meraup uang kembali (korupsi, kolusi, dan nepotisme); apabila rakyat masih saja suka ditipu, maka para politisi akan terus menjual tipuan (pembodohan) dan seterusnya. Artinya, kondisi perpolitikan Indonesia dibawah sistem demokrasi sepenuhnya tergantung dari kehendak rakyat.

Arus perputaran politik merupakan kehendak mutlak rakyat, baik dalam kontestasi (sebagai calon maupun penggunaan suara dalam pemilihan umum), menyangkal dan menerima berbagai kebijakan politik untuk kehidupan lebih baik. Landasannya jelas, yaitu konsensus daripada warga Negara, mulai dari Pancasila, UUD 1945, NKRI, dan Bhineka Tunggal Ika. Namun bagaimana pun kondisinya, hukum demokrasi tetaplah berlaku secara otomatis. Akan tetapi bukan berarti menerima suatu kondisi yang dihasilkan dalam demokrasi Indonesia selama ini sebagai kutukan, selalu ada kesempatan untuk memperbaiki kualitas demokrasi, dan itu hanya mampu dilakukan oleh rakyat Indonesia.

\section{Faktor-Faktor Maraknya Politik Kekerabatan}

Merujuk dari penelitian Ayuni, N., F., tahun 2016 tentang partisipasi politik rakyat pada Pemilihan Bupati Tahun 2013 di Kabupaten Penajam Paser Utara mengemukakan partisipasi politik rakyat memiliki signifikansi dari kesadaran politik. Penelitian dan hasil serupa dikemukakan oleh Mery, A., Asrinaldi, dan Aidinil, Z., (2018) di Kabupaten Dharmasraya pada Pilkada 2015 bahwa kesadaran politik memiliki hubungan positif dengan partisipasi politik rakyat. Dapat diartikan keterlibatan rakyat dalam perpolitikan untuk menentukan sikap dan posisinya (bersifat aktif maupun passif) sangat tergantung pada kesadaran politik rakyat itu sendiri. Implikasinya adalah jika setiap pilkada terjadi peningkatan politik kekerabatan, maka dapat dinyatakan bahwa partisipasi politik rakyat bersifat passif dikarenakan kesadaran politik masih rendah. Sebagaimana hal ini telah diungkapkan dalam studi systematic literature review Agus S., (2017) yang memperlihatkan bahwa fenomena tersebut sebagai gejala proliferasi politik kekerabatan dengan ungkapan bahwa praktik politik kekerabatan juga terjadi di Banten mengimplikasikan adanya gejala persebaran (proliferasi, pertumbuhan) yang tidak hanya pada ranah kekuasaan eksekutif maupun legislatif, melainkan menyebar juga di banyak arena kehidupan rakyat, seperti pada arena kehidupan sosial, budaya, bisnis, pendidikan, dan lainnya. Proliferasi politik kekerabatan merupakan strategi unik dalam perpolitikan demokratis melalui populisme politik yang terbentuk kuat dari lemahnya kesadaran politik rakyat.

Dampak dari kesadaran politik rakyat yang masih rendah menjadi keresahan akademis bagi peneliti bernama Catur, P., P., sehingga melakukan penelitian pada tahun 2018 tentang Pilkada 2015 di Kabupaten Klaten dengan menyatakan bahwa rakyat menganggap politik kekerabatan sebagai suatu kewajaran. Anggapan rakyat demikian mengantarkan pada suatu pemahaman bahwa bahaya laten dalam demokrasi berada pada tingkat darurat. Sebab dengan anggapan tersebut terhadap fenomena politik kekerabatan tidak hanya pemakluman, melainkan sudah masuk pada tahap pembiaran. Lebih jauh lagi, pembiaran politik kekerabatan yang dilakukan oleh rakyat memberikan ruang bebas untuk para aktor elit demokrasi melanggengkan birahi politiknya menguasai posisi-posisi strategis kerakyatan.

Selanjutnya, Cecep, N., N., dan Cecep A., C., (2019) mencoba untuk menyingkap faktor substantif atas fenomena maraknya politik kekerabatan dengan melakukan penelitian 
tentang hubungan dari pendidikan politik terhadap tingkat partisipasi politik rakyat pada pilkada di Kabupaten Kuningan dengan temuan hubungan dari pendidikan politik terhadap partisipasi politik pada pilkada memberikan pengaruh yang positif, ditandai dengan adanya peningkatan partisipasi politik rakyat. Ini mengindikasikan bahwa tingkat kesadaran politik rakyat rendah berbanding lurus dengan pendidikan politik yang diberikan kepada rakyat juga rendah.

Sehingga partisipasi politik rakyat pada pilkada hanya bersifat partisipasi dalam pemberian suara dan apathy total. Adapun faktor-faktor yang membentuk kondisi partisipasi rakyat demikian pada pilkada adalah kepercayaan terhadap pemerintah, sistem rekrutmen politik oleh partai politik, dan pemutakhiran data pemilih (Faiz, A., N., Muhammad H., T., dan Alwi D., R., 2020). Berbeda dengan temuan penelitian Inggried, F., M., dan Dewi, E., (2020) yang menunjukkan rendahnya partisipasi rakyat pada pilkada juga dipengaruhi oleh kurangnya kepercayaan rakyat terhadap pemerintah dalam mengantisipasi konflik antar pendukung pasangan calon. Sering terjadinya konflik horizontal dalam tubuh rakyat pasca pemilihan kepala daerah memang tidak bisa dinafikkan. Bahkan kepala daerah terpilih jarang untuk melakukan perbaikan terhadap konflik rakyat, seolah-olah rakyat yang tidak memilihnya bukanlah bagian dari rakyat daerah tersebut. Polarisasi dengan mobilisasi rakyat pada pilkada dengan kondisi demikian menunjukkan betapa pemerintah daerah terpilih bersifat kekanak-kanakan.

Siti, K., R., (2018), terbentuknya fenomena hingga terpilihnya pemerintah daerah yang kekanak-kanakan disebabkan oleh persyaratan calon eksekutif di pilkada tidak terletak pada ketentuan subtantif, melainkan hanya pada ketentuan normatif; lemahnya sosialisasi KPU kepada mayarakat; penyelenggara pemilihan umum kepala daerah tidak memiliki pengalaman dalam pekerjaan yang sedang dihadapinya; ketidakpercayaan terhadap calon kepala daerah, baik ketidakpercayaan terhadap janji kampanye maupun ketidaktertarikan dengan visi dan misi yang dibawakan; serta tingginya modus transaksi atau pemberian hadiah dari calon kepada rakyat selaku pemilih. Tingginya modus transaksi dari calon kepala daerah pada rakyat juga diiringi dengan minimnya pemberdayaan ruang publik dengan suburnya praktik-praktik money politic (Muten, N., dan Roy, M. M. 2019). Praktik-praktik politik uang yang berlangsung ditengah rakyat setidaknya memiliki tiga konsekuensi logis, yaitu menciptakan politisi korup, mengekang hati nurani rakyat memberikan partisipasi politiknya, dan mencederai pemilu demokratis.

Berangkat dari kerangka pemikiran Siti diatas, pun tidak bisa dinafikkan bahwa ketentuan untuk menyaring politik kekerabatan merupakan salah satu penyebab utama dari maraknya politik kekerabatan dalam Pilkada. Melalui UU Nomor 1 Tahun 2015 tentang Pilkada pada Pasal 7 poin q sebenarnya menjadi oase ditengah suburnya politik kekerabatan melalui pendekatan "larangan konflik kepentingan". Akan tetapi semenjak UU tersebut diubah menjadi "UU Nomor 6 Tahun 2020 tentang Penetapan Peraturan Pemerintah Pengganti Undang-Undang Nomor 2 Tahun 2020 tentang Perubahan Ketiga atas UndangUndang Nomor 1 Tahun 2015 tentang Penetapan Peraturan Pemerintah Pengganti UndangUndang Nomor 1 Tahun 2014 tentang Pemilihan Gubernur, Bupati, dan Walikota" telah terjadi pembukaan kran politik kekerabatan secara leluasa.

\section{Insecurisme Politik Rakyat Indonesia}

Sebagaimana fator-faktor diatas membentuk tingkat partisipasi rakyat dalam perpolitikan demokrasi telah menjadi pemahaman kolektif-kolegial dalam tubuh rakyat. Penelitian tentang kondisi tersebut telah diungkapkan oleh para peneliti, mulai dari Catur, P., P., (2018) ; Siti, K., R., (2018) ; Faiz, A., N., Muhammad H., T., dan Alwi D., R., 2020 ; dan 
Inggried, F., M., dan Dewi, E., (2020) yang mengemukakan bahwa rakyat telah beranggapan bahwa partisipasi mereka (aktif maupun passif) tidak memberikan pengaruh apa-apa.

Secara teoritis, politik yang sedang melanda Negara kita dengan manuver oligarki maupun dinasti terlihat jelas. Dimana saat kalangan aktor elit dan kalangan rakyat kelas menengah kebawah memiliki ketidaksamaan dalam posisi sosial, terlebih posisi politik. Dan hal tersebut merupakan bunyi dari teori elite. Terbentuknya politik kekerabatan yang semakin mengakar dengan kuat dan tumbuh subur di bumi pertiwi ini menyebabkan insecurisme politik rakyat. Artinya partisipasi politik, daya literasi politik, dan preasure politik dari rakyat semakin lemah sehingga menjadi ketidakpercayaan dan ketidakberdayaan rakyat mengikuti kontestasi politik secara tegas adalah realitas dari perpolitikan demokrasi Indonesia. Insecurisme politik rakyat ini penulis turunkan dari artikel penulis sebelumnya yang berjudul "Menyingkap Psikologi Politik Indonesia". Dalam memahami psikologi politik demokrasi tidaklah begitu sulit. Sebagaimana kita ketahui bahwa politik dikendalikan oleh satu-kesatuan sistem, politisi, pemilih, dan regulasi (UU) yang mekanismenya terbentuk dari hukum stimulus dan respon. Sederhananya, penulis merumuskan bentuk psikologi politik sebagai berikut "Psikologi politik = Regulasi : [Politisi : Pemilih]". Dengan kata lain, kuat atau tidaknya regulasi dalam kontestasi demokrasi mempengaruhi secara langsung dan begitu signifikan terkait kondisi pemilih menstimulus pemimpinnya yang berkualitas dan berintegritas dalam mewujudkan tujuan bersama (citizen welfare).

Meninjau dari perspektif teori keturunan, seseorang yang berasal dari keturunan pemimpin akan memiliki peluang dari posisinya untuk mengisi ruang kepemimpinan tersebut. Bahkan, sebelum demokrasi terbangun dengan baik, bukankah kita mengetahui bahwa semasa kerajaan adalah keturunan menjadi cara pergantian kepemimpinan. Lagi-lagi cara pergantian itu secara terselubung (bahkan secara terang-terangan sudah dianggap sebagai hal wajar oleh rakyat) dipergunakan pada konstruksi demokrasi Indonesia hari ini.

Siapa yang bisa membantah bahwa perpolitikan kita dewasa ini sedang mengalami perkawinan antar elit (elit politik, elit sosial, elit agama, elit ekonomi, dll.)? Meletakkan modal sebagai kekuatan utama dalam mencapai kekuasaan. Oleh karenanya, posisi politik yang telah diamanatkan konstitusi tidak lagi sejalan dengan penerapannya, orang-orang dalam lingkaran aktor elit (politik kekerabatan) memperoleh ruang dan kesempatan utama dibandingkan kalangan kelas kecil yang memiliki kemampuan memimpin lebih. Lagi pula, bukankah perpolitikan kita butuh ongkos dalam prosesi pemilihan kepemimpinan, nominal itu tidaklah ringan bagi kelas menengah kebawah.

Seyogyanya rakyat selalu menghendaki perubahan melalui upaya perbaikan secara berkesinambungan. Tidak lain yang rakyat inginkan hanyalah perbaikan kualitas hidupnya. Menjelang berbagai kontestasi demokrasi, baik itu pilpres, pileg, dan pilkada rakyat kerap memunculkan kerinduannya pada perbaikan. Misalnya ketika kita menanyai ibu-ibu penjual sayuran, sopir angkot, buruh pabrik, buruh tani, dan lapisan rakyat menengah kebawah lainnya sering terdengar keluhan yang sama, "tidak peduli siapa presidennya, mau siapa yang menjadi legislatif, ataupun tokoh seperti apa yang akan memimpin daerahnya". Ungkapan tersebut terkesan politik apatisme rakyat, namun kalau melihat lebih dalam lagi, ungkapan tersebut mengisyaratkan adanya perubahan dan perbaikan kualitas hidup yang konkret dan subtantif.

Akan tetapi, kehendak rakyat ini selalu dijawab melalui retorika populis oleh partai politik melalui calon yang mereka usung maupun melalui tim (pihak terkaitnya). Rakyat disuguhkan dengan janji-janji hingga pada pembodohan melalui pemberian uang rokoklah namanya (money politics) sehingga dilematis rakyat semakin menjadi-jadi dan problematika yang bersarang dalam tubuh rakyat tidak pernah selesai. Mulai dari kemiskinan, pemukiman 
kumuh, petani dan hasil pertanian semakin anjlok, buruh tertindas, nelayan tak kunjung sejahtera, korupsi dimana-mana, nepotisme tumbuh sistemik, dan berbagai problematika serta patologi rakyat bernegara lainnya.

Komoditas politik dan partai politik pada pemilihan kepala daerah kerap bersifat "populis dan populisme" yang telah berhasil secara electoral. Maksud daripada populis dan populisme dalam tulisan ini adalah terkesan menjadi kepercayaan bagi rakyat atas permasalahan-permasalahan kerakyatan selama ini. Bahkan apabila menyingkap tabir dari populisme politik dan politisi populis, ini telah menjadi konsekuensi suburnya pertumbuhan dari politik kekerabatan. Merujuk dari penelitian Muddle, Cas, dan Kaltwasser (2017) menemukan hasil bahwa jualan "populis" telah berkembang pesat mulai dari Eropa Barat hingga India dan Amerika. Ide-ide populis telah menjadi komoditas arus utama politik dan tentunya populisme merupakan tantangan untuk musyawarah demokratis. Fenomenanya, mengutip studi Richmond \& Porpora (2019) bahwa politisi populis biasanya hadir dengan berbagai dalih yang membuat rakyat selaku pemilih terbuai dan dilema. Masuknya politik kekerabatan melalui konsep populisme adalah dengan meyakinkan rakyat bahwa mereka berasal dari lingkaran elit yang sudah memiliki modal lebih dari cukup, sehingga nampaknya korupsi tidak akan mereka lakukan dan mengagendakan prioritas pembangunan bagi rakyat.

Politisi populis cenderung menjanjikan lebih dari yang dapat diberikan (yaitu, mereka tidak memiliki solusi yang layak), sehingga mengungkapkan perbedaan antara janji dan kenyataan harus menjadi strategi pesan yang efektif bagi rakyat (selaku penentu). Tentunya, para politisi yang hadir dengan ketulusan dan kemampuan lebih untuk memperbaiki kondisi demokrasi dan rakyat tidak cukup meyakinkan bahwa ia-lah yang dapat memberikan solusi terhadap permasalahan rakyat. Yang terbentuk dari dua arus politik tersebut membuat ketidakjelasan dalam klaim retoris bagi rakyat dan mengidentifikasi pergeseran naratif politisi. Lagipula telah banyak penelitian menunjukkan bahwa politisi yang berasal dari lingkaran aktor elit menjadi lebih populis dan mendapatkan banyak dorongan daripada politisi yang berasal dari lingkaran aktor elit (Damstra, Jacobs, Boukes, \& Vliegenthart, 2019).

Fakta empiris juga memperlihatkan bahwa para politisi populis selalu menggunakan pola menyalahkan elit politik (kambing hitam) karena tidak mewakili rakyat biasa dan keinginan mereka. Dibalik tabir tersebut, politisi populis yang hadir juga merupakan bagian dari aktor elit. Dengan kata lain bahwa pertarungan antar aktor elitlah yang sedang terjadi ditengah kegaduhan politik dalam rakyat. Penelitian tentang fenomena ini dilakukan oleh Pawennari, H., dan Lia. A., tahun 2019 tentang politik kekerabatan yang terjadi pada pilkada di Kabupaten Bone dengan temuan bahwa yang terjadi ditengah rakyat sebagai instrument politik adalah pertarungan antar keturunan bangsawan.

Sebagaimana studi Moffitt (2017) mengungkapkan bahwa kaum populis sering merujuk pada krisis negara yang parah sebagai dalih, sedangkan "rakyat" ditampilkan sebagai kelompok yang relatif tidak berdaya. Namun, solusi dari politisi populis untuk menyelesaikan krisis yang dirasakan seringkali sederhana, tidak jelas, dan tidak dapat dilakukan rekomendasi. Lagi-lagi hal ini tidak lain juga dipengaruhi oleh sikap pragmatism aktor elit politik dan anggapan tidak layak maupun tidak mampunya (insecure) dari rakyat dalam berkontestasi politik.

Sehingga pelibatan diri terhadap isu apa pun dalam agenda kebijakan dilaksanakan secara kompetitif oleh para aktor demokrasi dengan membawakan berbagai kepentingan (mulai dari elit politik, elit sosial, pengusaha, dan pihak kepentingan lainnya) berbanding lurus yang mendominasi keterlibatan rakyat dengan apatisme politik dan daya literasi politik yang rendah. Ketika suatu masalah diterima dalam agenda kebijakan, rakyat tetap tenang 
dengan posisinya seolah-olah kebijakan dan kondisi yang berlangsung memberi harapan bahwa masalah mereka mendapat perhatian. Namun karena kurangnya pemahaman rakyat terhadap perannya dalam demokrasi, muncullah berbagai patologi politik yang berdampak langsung terhadap insecurisme politik rakyat. Salah satu indikator dari insecurisme politik rakyat di Indonesia adalah maraknya politik kekerabatan yang kemudian dianggap bukan suatu masalah oleh rakyat itu sendiri.

Politik kekerabatan merupakan strategi elit aktor demokrasi (baik elit politik, pengusaha, agama, social, dan lainnya) untuk menguasai jabatan-jabatan strategis perpolitikan dari lingkar kekerabatan para elit itu sendiri. Di Indonesia, politik kekerabatan menjadi salah satu patologi politik yang sangat berbahaya, meniadakan chek and balance dalam sistem trias politica lembaga kenegaraan, memperkuat cengkraman plutokrasi pemerintahan, dan membentuk keterpurukan bangsa melalui politik kekerabatan serta oligarki kekuasaan.

Selain dari faktor-faktor diatas, tingginya peningkatan politik kekerabatan tidak lepas dari peran partai politik. Oligarki di tubuh partai politik menjadi penyebab kandidasi dan penjaringan calon tidak berjalan tepat semestinya. Selama ini terdapat kecenderungan kandidasi calon kepala daerah partai politik berdasarkan keinginan dari elit partai, tidak dilakukan secara demokratis yang mempertimbangkan kualitas kelayakan dalam memimpin untuk membangun, mulai dari kapabilitas, integritas, mentalitas, dan profesionalitas calon.

Fenomenanya, politik kekerabatan secara terus menerus berupaya membangun jaringan kekuasaan dengan kuat dalam rangka mempertahankan kekuasaannya di tubuh partai politik yang tujuan utamanya adalah pasti hendak menguasai jabatan-jabatan strategis perpolitikan Negara mulai dari tingkat daerah hingga pusat. Dari posisi rakyat yang notabenenya masih lemah dalam literasi menciptakan konsekuensi logis untuk memunculkan sinyalemen mempertahankan status quo di daerahnya dengan tetap mendorong kalangan kerabat maupun orang terdekat dengan kepala daerah sebelumnya.

Oleh karena itu, dampak paling nyata dari insecurisme politik rakyat adalah maraknya politik kekerabatan pada pemilihan kepala daerah dan fenomena calon tunggal. Merujuk dari hasil rekapitulasi KPU, terdapat 25 daerah dengan kondisi calon tunggal yang semua calon tunggal tersebut berhasil memperoleh kemenangan. Jika melihat kembali penyelenggaraan pilkada serentak tahun-tahun sebelumnya, tren kandidasi calon tunggal pada kontestasi pilkada juga mengalami peningkatan yang signifikan. Pada pilkada 2015 ada 3 daerah, pilkada serentak 2017 sebanyak 9 daerah, Pilkada 2018 ada 13 daerah yang melaksanakan pemilihan kepala daerah dengan hanya satu calon, dan pilkada pada tahun 2020 meningkat jauh dengan angka 25 daerah. Calon tunggal tetaplah bagian dari strategi aktor elit untuk memenuhi birahi kekuasaan atas jabatan-jabatan strategis. Melalui dominasi kekuatan politik, finansial, dan modal sosial para elit membuat rakyat yang potensial dan layak untuk memimpin tidak berani bertarung dalam kontestasi (insecurisme politik rakyat).

\section{Dampak Insecurisme Politik Rakyat Indonesia}

Kerap ditemui para pengsisi instansi diberikan kehendak untuk menyesuaikan posisi instansinya dalam memberikan bantuan dan perlindungan kepada hubungan kerabat maupun lingkar kekerabatannya yang tidak lain dengan maksud memperbaiki kondisi material mereka. Keadaan ini biasanya disambut dengan sorak-sorai kegembiaraan mereka yang ditunjuk. Kegembiraan yang tidak berasal dari kenyataan bahwa mereka diangkat telah diberi kesempatan untuk melayani negara, melainkan berasal dari fakta bahwa orang yang diangkat akan menggunakan wewenang diskresi dari instansinya untuk meningkatkan standar hidupnya. 
Ketika posisi publik yang kosong harus diisi dan nepotisme menjadi alih-alih pantas memilih yang bersangkutan adalah "sesuai dengan kriteria" kandidat untuk pekerjaan tertentu. Mungkin secara awam kebanyakan dari kita menyatakan bahwa proses seleksilah yang telah rusak jika menemukan berbagai pelayanan yang tidak layak dan kebijakan amburadul. Tidak seutuhnya salah, sebab semuanya memiliki keterkaitan, namun lebih dalam lagi bahwa kesengajaan adalah penyebab utamanya. Cara memandang terhadap tindakan bobrok seperti itu harus dilakukan secara holistik. Meskipun kekuatan sistem yang subur untuk "saat ini" adalah ekonomi kapitalis pinggiran dan dioperasikan sedemikian sistemik di Indonesia. Menciptakan kekuatan politik sebagai akumulasi primitif. Jika ada pengembangan tingkat tinggi terhadap upaya-upaya produktif, ekonomi akan lebih berorientasi pada produksi daripada berorientasi pada apropriasi. Akan tetapi, lagi-lagi, kita harus memahami bahwa nepotisme malah akan menjadikan berbagai hal yang kontra-produktif. Klausalitasnya, jabatan publik akan menjadi kurang menarik. Sehingga kontestasi politik menjadi kurang ganas, pejabat publik menghadapi kurangnya tekanan atas keuntungan pribadi dari konstituen yang mereka lakukan. Pun hal ini menjadi penyubur dari tindakan nepotisme, bahkan sudah begitu sering terjadi dari sebelum-sebelumnya, namun ia bangkit lagi dan semakin subur. Dengan demikian, keberhasilan seorang pejabat publik diukur bukan lagi dari hal pemenuhan mandat inti yang dituntut oleh instansinya, tetapi tentang bagaimana ia menggunakan perlengkapan posisi untuk meningkatkan kondisi kehidupan kerabat dan kroninya.

Para pejabat publik yang melakukan nepotisme tidak sungkan-sungkan mengucilkan rakyat lainnya, meskipun orang paling kompeten dengan posisinya harus dikorbankan. Semestinya, mereka-mereka ini (para pejabat publik) harus memperoleh banyak tekanan dari rakyat untuk melaksanakan TUPOKSI-nya dengan sebaik-baiknya. Memberikan hukuman politis dan sosial tidak tanggung-tanggung, demi terwujudnya tujuan Negara sebagaimana amanat konstitusi kita sehingga berimplikasi pada upaya-upaya peniadaan tindakan nepotisme yang amat merugikan ini. Akan tetapi karena rakyat sudah merasa insecure untuk bertindak, terjadinya pembiaran dari rakyat dan seolah-olah yang terjadi adalah hukum alamiah demokrasi dengan semua momok kebobrokan. Berbagai studi membenarkan keadaan ini dengan alasan sistem keluarga besar yang dipraktikkan di Indonesia, siapapun tidak bisa menyangkal keadaannya.

Upaya untuk memenuhi segala perbuatan tersebut, jasa dan keadilan dikorbankan di altar nepotisme. Bagi kita mungkin hal tersebut adalah tekanan, berbeda bagi mereka yang malah menjadikannya sebagai kekuatan untuk melakukan hal-hal yang tidak etis. Ini juga (bahkan berpotensi besar) menjadi pengalihan dan penyalahgunaan anggaran Negara (korupsi dan suap). Di lain waktu, proyek infrastruktur pemerintah dialihkan ke lokalitas pejabat publik, meskipun tidak masuk akal secara ekonomi. Kita harus jujur bahwa semua anomali ini sudah lama dan masih berlanjut hingga kini, kapan berakhirnya adalah sebuah misteri paling sukar ditebak. Pelayan publik terus menerima pujian dari kerabatnya dan mengagungkan fakta bahwa ia tahu bagaimana menggunakan kekuatan untuk menyejahterakan sesamanya dan rakyat biasalah yang menderita. Tidak ada yang dilakukan dalam "melayani rakyat", sialnya tidak dianggap sebagai kesalahan. Pun telah bermetamorfosis menjadi kebiasaan sepanjang peradaban pertiwi. Jelas, semua itu adalah kebiasaan buruk yang bisa dikatakan dipegang teguh di Indonesia, akibatnya para pejabat publik cenderung melakukan korupsi. Atas dasar kondisi ini, kita dipertontonkan sebuah ketidakmungkinan bahwa para pelayan publik bisa didakwa pidana walau diajukan kepadanya di pengadilan. Para kroninya akan menafsirkan dakwaan tersebut sebagai penganiayaan politik (pembelaan dan pembenaran). Mereka akan memobilisasi solidaritas ke pengadilan untuk menunjukkan "eratnya hubungan" dengan terdakwa. Dengan demikian, 
kriminalitas dirasionalisasi dan dirayakan oleh penerima manfaat. Sebenarnya, hal ini adalah corengan wajah yang memalukan bagi Indonesia; korupsi, oportunisme, dan tidak adanya prinsip.

Relevansinya adalah, "jika perjalanan akan dimulai, kaki kanan akan melangkah yang kemudian diikuti oleh langkahan kaki kiri sebagai penyeimbang tercapainya tujuan". Artinya, pihak yang angkat harus mengikuti kehendak dari pihak yang memasukkan. Namun, biasanya ini dilakukan untuk tujuan korup bersama. Sebagaimana studi empiris yang dilakukan oleh Pramana R. B., Rahman F., Karuza N. P., Hanafi R. S., Rahmani A. A. N., Tsaqila N. Q., dan Daulay L. Z., (2020) bahwa dalam pilkada 2020 terdapat kekhawatiran masyarakat terhadap praktik money politik berdasarkan responden dimana sebanyak $76 \%$ orang khawatir praktik money politic atas nama bantuan Covid-19. Hukum stimulus-respon berlaku, membuat orang lain melakukan sesuatu yang ilegal. Dalam hal demikian, orang yang memberikan money politics dalam berbagai bentuk akan berharap bahwa suatu hari, penerima akan memiliki alasan untuk datang kepadanya lalu meminta bantuan agar dipenuhi juga. Namun hal ini sering disamarkan, tindakan semacam itu telah menemukan akomodasi dalam budaya dan sistem demokrasi Indonesia. Dan kondisi ini merupakan dampak dari insecurisme politik rakyat paling berbahaya dan akan berkelajutan pada lingkar api demokrasi yang bobrok.

\section{Kesimpulan}

Berdasarkan temuan dan pembahasan diatas, penulis menarik kesimpulan bahwa faktor substantif yang menyebabkan partisipasi politik rakyat rendah pada pilkada 2020 ada 8 (delapan), yaitu kesadaran politik rakyat masih rendah, minimnya pendidikan politik kepada rakyat, partisipasi politik rakyat bersifat passif dan apathy total, rekruitment partai politik pada kandidasi calon kepala daerah, ketidakpercayaan rakyat terhadap calon kepala daerah, lemahnya sosialisasi KPU terhadap rakyat tentang pentingnya penggunaan suara mereka dalam menentukan kondisi daerah, pemutakhiran data pemilih, dan tingginya modus transaksi (termasuk money politik) calon kepala daerah kepada rakyat.

Faktor-faktor diatas menjadi penyebab maraknya fenomena politik kekerabatan pada pilkada 2020 yang diperkuat dengan 2 (dua) faktor substantif, yaitu ketentuan untuk calon kepala daerah hanya bersifat normatif dan kran politik kekerabatan yang dibuka secara leluasa melalui UU Nomor 6 Tahun 2020 tentang Penetapan Peraturan Pemerintah Pengganti Undang-Undang Nomor 2 Tahun 2020 tentang Perubahan Ketiga atas Undang-Undang Nomor 1 Tahun 2015 tentang Penetapan Peraturan Pemerintah Pengganti Undang-Undang Nomor 1 Tahun 2014 tentang Pemilihan Gubernur, Bupati, dan Walikota.

Lebih lanjut, analisis mendalam dari penulis terhadap temuan diatas adalah bahwa telah terjadinya insecurisme politik rakyat Indonesia pada pilkada 2020. Rakyat memposisikan dirinya tidak berdaya dan tidak memiliki pengaruh (insecure) dalam demokrasi melalui partsipasi aktif perpolitikan yang konstruktif sehingga melakukan pembiaran atas maraknya politik kekerabatan. Padahal ruh daripada Negara demokrasi adalah rakyat. Kondisi tersebut terbentuk dari keberhasilan oleh para aktor elit menghadirkan politisi lingkar kekerabatan yang populis. Membuat rakyat beranggapan bahwa kehadiran para politisi populis dengan kekayaan yang dimiliki tidak akan korupsi dibandingkan politisi diluar dari aktor elit dan nampaknya rakyat dijadikan sebagai prioritas.

Insecurisme politik rakyat juga terbentuk dari ketidakpedulian pilar-pilar demokrasi terhadap rakyat. Partai politik, pendidikan tinggi, dan ormas yang tidak melakukan fungsinya untuk mengedukasi rakyat agar kesadaran politik dan daya literasi politik rakyat menjadi tinggi. Rakyat beranggapan bahwa mereka tidak dipedulikan dan menarik diri untuk 
menerima kutukan para skandal politik (bahwa rakyat selalu tidak berdaya dan lemah) yang menjadikan rakyat hanya berfungsi sebagai pemilih.

Dalam demokrasi, rakyat adalah penentu kondisi daerah bahkan negara melalui kehendaknya, tidak hanya pemilih pada kotak suara. Rakyat harus segera menyadari ini. Logika demokrasi di Indonesia yang dimaktubkan dalam konstitusi (UUD 1945) berbeda dengan demokrasi di Negara-negara lain belahan dunia, bahwasanya demokrasi memberikan sepenuhnya kendali ditangan rakyat. Sehingga demokrasi bukanlah normalisasi atas kedaruratan untuk Indonesia yang berasal dari Negara. Dampak dari sikap insecure politik rakyat menjadi bahaya laten dalam demokrasi adalah nepotisme dan korupsi yang sistemik. Para aktor elit akan terus mempertahankan status quo (membuat rakyat beranggapan bahwa rakyat itu lemah) sebagai strategi melanggengkan birahi kekuasaannya untuk menguasai sektor-sektor strategis kerakyatan.

\section{Daftar Pustaka}

Buku:

Chilcote, R.H. (2003). Teori Perbandingan Politik: Penelusuran Paradigma. Jakarta: Raja Grafindo Persada.

Mudde, Cas, and Kaltwasser CR. (2017). Populism. A Very Short Introduction. Oxford: Oxford University Press.

Artikel Daring:

Jati W. R. (2021). Fenomena Kemunduran Demokrasi Indonesia 2021. Diakses pada tanggal $10 \quad$ Juni 2021 dari https://www.habibiecenter.or.id/img/publication/ac06aed73a921420af78a420d4f6f50c. pdf

Artikel dari Jurnal Daring:

Agus, S. (2017). Gejala Proliferasi Politik kekerabatan di Banten Era Kepemimpinan Gubernur Ratu Atut Chosiyah (hlm. 100-120). Politik Indonesia: Indonesian Political Science Review, Volume 2, Nomor 2. https://journal.unnes.ac.id/nju/index.php/jpi/article/view/9329/6436

Agustino, L., \& Yusoff, M. (2020). Pilkada dan Pemekaran Daerah dalam Demokrasi Lokal di Indonesia: Local Strongmen dan Roving Bandits (hlm. 86-104). Jebat: Malaysian Journal of History, Politics \& Strategic Studies,Volume 37. https://ejournal.ukm.my/jebat/article/view/42224

Ardiyanti, Dwi \& Zulian, Ibnu (2018). Korelasi Identifikasi Apatisme Politik Dengan Kebijakan Publik Kota Medan (hlm. 29-53). Jurnal Power in International Relation, Volume $\quad 03, \quad \quad$ Nomor $\quad 01 . \quad \underline{\text { htp://e-journal.potensi- }}$ utama.ac.id/ojs/index.php/PIR/article/view/445

Ayuni, N., F. (2016). Pengaruh Kesadaran Politik terhadap Partisipasi Politik Rakyat dalam Pemilihan Bupati Tahun 2013 di Desa Sesulu Kabupaten Penajam Paser Utara (hlm. 1615-1626). E-Journal Ilmu Pemerintahan, Volume 4, Nomor 4. https://ejournal.ip.fisip-unmul.ac.id/site/?p=2171

Catur, P., P. (2018). Politik Kekerabatan di Pilkada: Studi Kasus Terpilihnya Pasangan Calon Hj. Sri Hartini S.E-Hj. Sri Mulyani pada Pilkada Kabupaten Klaten Tahun 2015 (hlm. 
221-230). Journal of Politic and Government Studies, Volume 7, Nomor 3. https://ejournal3.undip.ac.id/index.php/jpgs/article/view/21135

Cecep, N., N., dan Cecep A., C. (2019). Pengaruh Pendidikan Politik terhadap Partisipasi Politik Rakyat dalam Pilkada (Studi pada Pilkada Bupati di Kabupaten Kuningan) (hlm. 50-66). Syntax Idea, Volume 1, Nomor 8. http://jurnal.syntaxidea.co.id/index.php/syntax-idea/article/view/102/161

Damstra, A., Jacobs, L., Boukes, M., and Vliegenthart, R. (2019). The Impact of Immigration News on Antiimmigrant Party Support: Unpacking Agendasetting and Issue Ownership Effects Over Time. Journal of Elections, Public Opinion and Parties, Pages 1-22. https://doi.org/10.1080/17457289.2019.1607863

Faiz, A., N., Muhammad H., T., dan Alwi D., R. (2020). Menakar Partisipasi Politik Rakyat Kota Medan Terhadap Pemilihan Walikota Medan Tahun 2020 (hlm. 97-113). POLITEIA: Jurnal Ilmu Politik, Volume 12 Nomor 2. https://talenta.usu.ac.id/politeia/article/download/3955/3077/14235

Inggried, F., M., dan Dewi, E. (2020). Menakar Partisipasi Politik Rakyat Kabupaten Tana Toraja terhadap Pemilihan Kepala Daerah (Pilkada) Tahun 2020 (hlm. 168-181). Jurnal Academia Praja, Volume 3, Nomor 2. https://ejournal.fisip.unjani.ac.id/index.php/jurnal-academia-praja/article/view/183/141

Mery, A., Asrinaldi, dan Aidinil, Z. (2018). Pengaruh Kesadaran dan Kepercayaan Politik terhadap Partisipasi Politik Rakyat Dharmasraya pada Pilkada 2015 (hlm. 109-132). Jurnal Madania, Volume 8, Nomor 1. http://ejournal.uinsuska.ac.id/index.php/madania/article/view/5676/3296

Muten, N., dan Roy, M. M. (2019). Kebebasan Hak Sosial-Politik dan Partisipasi Warga Negara dalam Sistem Demokrasi di Indonesia (hlm. 110-127). Jurnal Ius Constituendum, Volume $\quad 4,4$ Nomor 2. http://journals.usm.ac.id/index.php/jic/article/view/1652/1135

Pawennari, H., dan Lia. A. (2019). Assajingeng: Politik Kekerabatan di PILKADA Kabupaten Bone (Analisis Antropologi Politik) (hlm, 121-134). Jurnal Socius: Journal of Sociology Research and Education, Volume 6, Nomor 2. http://socius.ppj.unp.ac.id/index.php/socius/article/view/161/41

Pramana R. B., Rahman F., Karuza N. P., Hanafi R. S., Rahmani A. A. N., Tsaqila N. Q., dan Daulay L. Z., (2020). Potensi Masalah Pilkada Serentak 2020 dan Kekhawatiran Masyarakat Pemilih Muda (hlm. 168-178). Kemudi: Jurnal Ilmu Pemerintahan, Volume 05, Nomor 02. https://doi.org/10.31629/kemudi.v5i02.2773

Richmond, JC., and Porpora, DV. (2019). Entertainment Politics as a Modernist Project in a Baudrillard World. Communication Theory, Volume 29, Issue 4, Pages 421440. https://doi.org/10.1093/ct/qty036

Siti, K., R. (2018). Partisipasi Politik Rakyat pada PILKADA 2017 di Kabupaten Yalimo, Papua, Indonesia (hlm. 109-124). SOSIOHUMANIKA: Jurnal Pendidikan Sains Sosial dan Kemanusiaan, $\quad$ Volume $11, \quad$ Nomor 1. http://journals.mindamas.com/index.php/sosiohumanika/article/view/1006/903

Majalah dan Koran:

Siagian, A. (Februari 2021). KEMATIAN DEMOKRASI: Diskursus Evaluatif Pilkada 2021. Mata Banua, hlm. 8.

Undang-Undang: 
Undang-Undang Nomor 6 Tahun 2020 tentang Penetapan Peraturan Pemerintah Pengganti Undang-Undang Nomor 2 Tahun 2020 tentang Perubahan Ketiga atas Undang-Undang Nomor 1 Tahun 2015 tentang Penetapan Peraturan Pemerintah Pengganti UndangUndang Nomor 1 Tahun 2014 tentang Pemilihan Gubernur, Bupati, dan Walikota. https://www.dpr.go.id/dokjdih/document/uu/1766.pdf 